\title{
医学図書館の未未来像
}

\section{Future of Medical Libraries}

\author{
慶應義塾大学 文学部 \\ 図書館・情報学科教授
}

津田良成*

\begin{abstract}
Medical libraries in past could enjoy a fairly steady growth and also a confidence in their capability to meet the most needs of their users. But, this comfortable situation is rapidly fading into an uncertain but somewhat dynamic environment. There are two major factors that cause this change. One is a social trend to make health and medical information available to much more larger population than those of physicians, such as, para-medical people, patients, and even to general public. Another is, of course, the development of new technologies represented by computer application to library and information service.

In Japan, the former factor is not so explicitly observed yet, however, the latter is recently getting to be an urgent one.

There are two entirely different attitudes we can choose to take in coping with this change of environment. We may stick to our traditional role of a custodian of book collection, and let other new-comers in our field of information transfer, such as the university computer center, to take over our job as the major information service unit in health and medical fields. Or, we may struggle to remodel ourselves to be able to fit better in the new role as much more active and dynamic information agent that will be needed in this new health and medical environment.

And if we choose the latter way, then, it would be necessary for us to fortify ourselves by acquiring more of medical knowledge so that we can be admitted as one of the true members of health care team.
\end{abstract}

\section{は しがき}

医学図書館は，わが国に打いては最も活発に活動して いる図書館であると考えられている。事実, 資料の相互 貸借サービスのネットワーク化, 総合目録の作成, 館員 の研修, 質の高い協会誌の発行などと, 日本医学図畫館 協会という組織を中心に, 多くの積極的な活動を行なっ ている。

\footnotetext{
* Yoshinari TSUDA : Professor, School of Library and Information Science, Faculty of Letters, Keio University. (昭和54年 5 月 15 日受理)
}

又，ゼロックスの図書館サービスへの導入，テレック スの相互貸借への利用, コンピュータによる雑誌の受入 れ記録のコントロール，特よび総合目録の編纂，ファク シミリによる文献コピーの電送実験など, 新技術の図書 館活動への利用に执いても多くの貢献をなしてきた。そ して現在では, いよいよ, 日本科学技術情報センター (JICST) のJOISのシステムを利用して, MEDLINE の データベースによる文献検索を, 日常サービスの一環と して取り入れるところになで到達した。 このような技術的变化は, 積み重なって段々大きなる 
のとなり，単に図書館サービスの一部が改善されて，利 用者が少し便利になるといった程度の变化ではなくなり 総合的には, 従来の図書館サービスに根本的な影響をも たらしか叔ない程になり始めている。

その上, 技術的問題とは全く別に, 社会的環境の变化 といらもが，図書館サービスの在り方を，更に大きく変 えようとしている。即ち, 近年に和ける社会組織の複雑 化が, そのサブシステムの一つである医学・医療システム をもどんどん複雑なものに変光，その構成要員も多くの グループに分れ，各々が強大なものになってきた。その 結果, 各グループ内ばかりでなく, グループ間の情報伝 達ということが強く必要とされるようになってきた。従 来, 医学・医療情報とい光ば, 注とんど医師と医師との間 を流れる知識としての情報を考えればよふったものが， 医師々, 看護婦, 薬剤士, 検查技士その他の医師以外の 医療従事者, 患者, 一般住民, 保健・医療行政汇たずさわ る人達, その他多くのグループを対象にする, 種々の情 報を考光なければならなくなってきた。

この事実は, 医学・医療情報伝達のための主要なシス テムの一つである医学図書館の活動目的にも, 当然影響 を与兄る筈である。事実, 欧米では, 医学図書館のサー ビス対象が急激に拡がり，現在では「医学図書館」とい ら名称も過去のものとなりはじめ,「保健科学図書館」 (health science library) といら呼び方が使用される 傾向にある。そして，パラメディカルの人達に対するサ 一ビスから, 更には, 患者や, 一般住民注対す保健医 学・医療情報の提供まで行うところが，増えてさてい る。

このような動きは，世界的なものであり，当然わが国 に执いても強くなってくることが予想される。

\section{I. 社会の変化と医学図書館}

医学・医療といらものは，本質的には病人を治痖する というところにあるのは，今も昔も同じであろう。たた 現在では, 医学・医療を, 単に病気を撚すばかりでなく 健康增進, 保健, 予防, 早期発見, 治療, リハビリテー ション, 福祉と, 幅広いスペクトルとして考えるように なってきている。

勿論, 現実の医学・医療の場に括いては, 従来からの 伝統の影響, 社会的条件などの理由により, 必ずしも保 健などの活動が，理屈ど特りに診療と同じ重みを持って 見られているとは限らないが，乙かし，将来に沶いては 保健に対する関心が益々強くなってゆくことは明らかで
あろら。

従来, 医学情報活動といえば, 前述のように, 医学研 究者, 臨床医などの間で発生した主として研究成果又は 観察の結果としての学術的な情報が, 他の研究者, 臨床 医, 又は医学教育者等によって研究, 診療, 教育などに 利用されることを意味していた。そしてその形態は, 学 会発表などの口頭による伝達型式のものを除くと, 新し い研究成果を記録して伝える学会雑誌の論文を中心とし た, 医学文献といら形で代表されていた。勿論, 文献の 中には，原著論文のようなオリジナルな研究成果を伝光 たり、ケースレポートのような新しい観察結果を伝觉る ことを目的としたものばかりでなく，特定主題に和ける 文献を展望して, その主題の現状 state of the art 学伝 えるものや，各専門分野の代表的な教科書の上うに，そ の分野の知識の集大成といった形のものなどのような解 説的な文献もある。又との他に学会・医療機関などに関 してや，各分野の新しい発見などについてのニュースの ような一過性の情報に類するもの定伝える文献も含まれ ている。しかし，これらの文献中の主流安なするのは， あくぬでも原著論文を主体とする学会誌などの学術雑誌 である。従って, 学会から自動的挲会員に配付される 所謂雑誌の一次配付 prìmary distribution が，その分野 の情報伝達の根幹をなしていた。しかしながら, 研究者 の增加と共に, 学会も細分化し, 且つ多様化して, 自分 自身の専門分野の文献ですら, 誰も, 十分に入手するこ とが出来なくなり, 徐々に, これら学会誌との他の文献 を組織的飞収集, 蓄積する図書館の利用, 即ち二次配付 secondary distribution に学術情報伝達の主座をゆずる ようになった。更に19世紀に出現した索引誌，抄録誌な ぞの発達により, この傾向は益々強化されていった。そ して現在では, 医学・医療分野の研究, 教育には, よく 整借された医学図書館を利用することが不可欠となって いる。医師に対する資料提供の面北関する限り, 医学図 書館は相当に効果的なサービスを提供できるようになっ てきているのである。

しかし，世の中の進歩とそれにともなら社会活動の複 雑化は, 図書館の周囲の環境というものをどんどん变化 させて特り,それに応じて, 図害館の役割りにも変化が 生じてきている。従って, 昨日十分であった図書館活動 も今日の時点でな特十分であるとは言いき礼なくなって きている。

その変化の一つは, 医療システムの複雑化にともなう パラメディカルの役割りの増大である。即ち，「チーム 
医療」といらものが単なる「扣題目」でなくなってきて いるのである。役割りの増大は責任の増大を意味し，同 時にパラメディカルの質の向上を必要とする。そして質 の向上は, 教育の改善及び, 研究活動の増加, その結果 としての文献の生産利用の増加につながる。しかし，従 来の医学図書館は， 汇とんど医師のみを利用者として考 えているために, 看護婦, 薬剂士, 検査技士, 栄養士そ の他の医療従事者の必要とする文献の収集, 提供につい ては余り配慮がされていないのが普通である。アメリカ などで “health science library”といら名称が “medical library”にとって変り出したのは, 図書館サービス の対象を医療従事者全般に拡げるようになってからのこ とで西る。わが国のこの分野の図書館活動は“health science library”を意味する適当な日本語が存在しない といらこともあろらが，未だに「医学図書館」であると いらところが，いささか気になる点である。

第 2 に, あげられる变化は, 医学図書館員の情報サービ ス面での機能の積極化を求める動きである。医学図書館 㥠来から, 企業体の図書館のように積極的な情報提供 サービスを行なってきて、る。例えば，わが国では，

MEDLINE の使用が可能になる以前から,「医学中央雑 誌」や「Index Medicus」などのような二次資料を使用 しての文献探索サービスが積極的に行われてきている。 しかし，これらの文献探索サービスは，利用者が図書館 にサービスを求めに来て初めて動き出す受身の形のサー ビスである。そして, Greenberg らがェール大学の医学 図書館で行ったMEDLINE 検索サービスの分析調査 ${ }^{13) 14}$ でも示めされているよらに，図書館が要求される文献探 索の大部分は, 研究和よび教育に必要な情報を求めるた めのもので, 直接患者の診療に関係のある情報要求は汪 んの一部 (エール大学の場合は約 $15 \%$ ) に過ぎない。

最近, アメリカ执よびカナダなどの一部の大学病院や その他の一般病院で, 患者の診療に役立つ情報を, より 積極的に臨床の医師に提供するためと，それらの臨床医 の診療の場での情報要求を, 図書館側がより正確に, よ り迅速に摑えることを主な目的として, 臨床医学図書館 員 (clinical medical librarian, CML 又は clinical librarian) という新しいタイプの役割りを持った図書館 員が使われるよらになってきている。

この試みを初めて実行に移したのは，カンサス・シテ ィーのミゾリー大学医学部の病院で, 内科の臨床教育を 受けている学生および residentsに, 患者の診療に直接 関係のある文献を提供することを目的とした。そのため
医学図書館は, 各臨床教育のグループに 1 人の CML を 配属して, 回診にもついて行かせ, その後の検討会, コ ンファレンスなどに出席して, 現場での医師と患者のや りとり, その後の討論などの情況から, 必要とされる情 報を見極めて，図書館に戻り，MEDLINE探索などを駆 使して適切な文献を見つけ，これをそのグループの医師 特よび学生に提供するというのが，このサービスの内容 である。

1972年にカリフォルニァで行われた, アメリカ医学図 書館協会の年次総会で, このサービスが発表されるや， 医学図書館員ばかりでなく，医師などの間にも大きな反 響を呼び，その動きが種々の雑誌に発表される122)478) 一 方, シカゴの Cock County 病院図書室25)や, シャトル のワシントン大学医学図書館 ${ }^{29}$ のように直らにこのサー ビスを実行に移すものが出てきた。そして，更に多くの 人達の関心を呼ぶようになった ${ }^{526) 23 \% 。 ~}$

CMLのサービスは, 病院のスタッフの間にも一般に 好感を持って受村入れられたが，その反面，病室への回 䛦の際の人数が増ることに対する疑問であるとか，CM Lにかかる人件費などの問題などについての反省も起っ た。

そこで, セントルイスのワシントン大学の医学部図書 館などでは，自己の行っているCMLサービスを(1)その 利用度，(2)かかった費用，(3)利用者の図書館利用態度の 変化, (4) CMLのクリニカル・コンファレンス出席の効 果，(5)費用を取っても利用されるかどうか, などの点に ついて評洒している。疏々の結果, CMLがサービスを提 供しているグループに属する医師は, 他の医師よりも遙 かに多い文献探索要求を行っていたことが判明した。そ して，その35\%の探索が直接患者の診療に関係したもの であった。このサービスにかかった費用は，1人の対象 residents 当り 1 ケ月 17 ドルであった。又わずかではあ るが，これらの residentsの日常に括ける圈書館利用の 増加が認められた。しかし，必要な費用は当然大学が持 つべきであるといら意見が圧倒的であった。同様の調查 がェール大学13)やロスアンジェルスのカリフォルニア大 学 (UCLA)11)で行われている。

このCMLサービスは, 医学図書館員を医療チームの 一員として位置づけるとに明らかに貢献し, 又, 医学 図書館サービスをより強く診療の場に結びつけるといら 点で成功していると言われている。病室の回診に図書館 員がついてゆくことはわが国の実情から言って，少くと も現時点では，とても考えられないここかも知れないが 
クリニカル・コンファランスに出席して, 臨床医師の情 報ニーズの実情を現場で捕兄, より迅速で適確な情報提 供サービスを試みることは, 今直ぐ実行に移すことも可 能な活動と考光られる。事実, CMLが，出現する前の 1976年からは, ジョージ・ワシントン大学とジョージタ ウン大学の両校医学部の教育病院である Washington Hospital Center では, 既に患者の診療の場に, 文献サ 一ビスを提供する LATCH (Literature Attached to Chart）と呼ばれるサービスが開始されている30)。

このサービスは, 臨床医が, 自分の担当の患者のうち 特に興味深いケースの病気について, 最近の文献情報の 提供を図書館に要求し，図書館は文献探索により見つか った文献中, 特に要求に適合するるのの幾つかのコピー を，その患者のカルテにつけて扔くといった形のもので ある。医師や看護婦に, 直接患者の病気住関係のある文 献を提供することになるため, 結果としては, 患者がよ りよい診療を受けることになる上, 四書館としても, こ

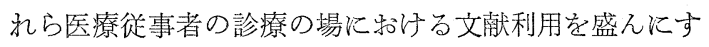
る結果になるため好評で，1968年から1975年迄の 8 年間 飞約2,000件の要求が要理されている。

又, タフト大学の医学 ・崡学図書館の場合の上らに 朝の病室への回診のあとで行われる“朝の報告”と呼ば れるコンファレンスにCMLが出席して，旮で取り上 げられる $2 \sim 3$ の特定のケースに関する短い文献りスト を作成したり，やはりそこで提案さ礼た，より広い主題 についてのレビュー文献を探索したりして，このグルー プに提供をすることを，CMLの主要なサービス7)とし ているところも㟧る。

但しこれらのサービスを行らためには，MEDLINE 検 索が十分に行充ないと，迅速な対応といら面で無理で㐫 ろら。しかし, カナダの McMaster 大学のCMLサー ビスの報告22)でも明白なように, CMLのサービスは, 現 在強く关の必要が認めら就始めている。医師以外の医療 チームメンバーや，患者に対する情報提供といら面の活 動に刘しても図書館サービスを拡げてゆくのに, 効果的 な踏み台となる可能性も持っているので, このサービス の採用を検討する必要は今後益々大きくなって行くであ ろう。

第 3 の変化は, 図書館サービスの対象が, 患者にまで 拡がり出したことである。患者への図書の提供サービス と言光ば, 従来から, アメリカの病院などでよく見られ る, 公共図書館サービスの延長とも言うべき患者図書室 の活動が考兄られる。そして, 最近ではこれら患者図書
室の活動の中に, 精神病患者の治療の一助とするための 図書館サービス ${ }^{9)}$ といったものる行われるよらになって きている。しかし，ここで論じる新しい図書館サービス とは患者への医学・医療情報の提供サービスである。前 述のカナダの McMaster 大学医学センターに掠ける CMLの活動は, 他のCMLサービスと異り, 医師ばか りでなく, 医師以外の医療チームのメンバーや患者をる そのサービスの対象としている。患者に対して, その病 気掞よび治療など関する情報提供の可否は, アメリカ に执いては少くとも過去20年程もの長い間, 盛ん飞諭じ られてきた問題である。しかし最近汇至って, (1)老人の 間に慢性の疾患が増加したこと, (2)医師が手術・投薬な どの処置を行ら時に患者の了解を求めることに関心を払 らようになったこと, (3)医師が他の医療チームのメンバ 一と診療の責任を分担する必要が出てきたこと, (4)消費 者の権利といら考光から患者がもっと情報を欲しがるよ らになったこと，5医療過䛊の訴訟などで，「患者の同 意」の有無が大切なポイントになっていること,などの 理由から患者注対する医学・医療の情報提供サービ久が 脚光をあびるようになってきた26)。

この必要性の台頭は, 図書館サービスの利用者として の患者を, テレビに奪われてきていた患者図書室のライ ブラリアンにとっては, 新しい存在理由艾獲得するよい チャンスとなった。ペンシルバニア州のPaoli Memorial 病院では, 患者のためのレファレンス・ライブラリーと いら企画を考光, 老人病, 保健, 安全, アルコール中毒 薬の乱用, 若い両親のための常識的な小坚科の知識, な ぞ関する図書やパンフレット類空, ブック・トラック 飞乗地て, 病室を回るサービスを1977年から開始してい る2甘。このよらな+ービスを行ならところふ, この病院 以外にもどんどん增えてきている。

患者に対して保健衛生教育といらるのを行らと, 患者 の入院している期間が実際に短縮したり, 再び病気にな って病院に戻ってくるケースが減るといった実際の統計 結果江基き，国民の医療費汸 1980 年代には国民総生産の 10\%にも達する程になってきたアメリカで性，この患者 に対する保健教育の実施を, 通常の医療行為の一部之乙 て, 真剣に考光ようとする動きが急激に拡がってきた。そ の中, 病院図書室によ爪患者に対する文献情報提供サ一 ビスといらあのは, だんだんと,根づきはじめている。15)

第 4 の变化は, 患者汶対する保健・医療情報の提供总 更に一歩超えた，一般住民に対する情報提供サービスの 必要性に刘する認識のたか乘りと，それにともなら，医 
学図書館のその方面へのサービスの提供を求める動きの たかまりをあげることができる。

この新しい局面の転回を生ぜしめた原因は二つあるよ 万淄思る。その一つは，国民対する保健・医療活動 の強化という広い観点から見た場合の一般地域住民の保 健・医療についてのより深い知識の必要性である。人口 10 万人当りの医師数が 160 名を超光る医療先進国のアメ リカでも, カリフォルニア大学地域医療学部の $\mathrm{R}$. Heifetz 教授によると, 一般地域住民は, (1) 病気に関連 して，自分が生存していくために必要な情報，(2)現存す る保健・医療サービスと先の性格についての情報, (3)健 康と病気济響を与学を球境の役割りについての情報, (4)自分の住んでいる地域ではどのような保健・医療の活 動計画やサービスを持つべきかを決めることが出来るよ らな情報等を必要としているといら。そのアメリカと拈 ける総医療費は1976年で1300億ドル，1977年で1600億ド ルと急激に增加しつづけ, 既に国民総生産 GNPの約10 \%にも達するところょで来ているが，病人の数は相対的 飞減少していない，しかる医療と呼べる活動の75\%は医

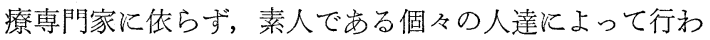
れているといらことが明らかにされている21)。又，これ ら一般住民の $29 \%$ \%, 保健・医療に関する情報の大部分 をテレビの番組から得て特り，そのテレビによる保健・ 医療情報の70\%は，内容が不正磪か，間違っているかの ぞちらかであると報告されている。

一方，医師数が人口 10 万人当り約 130 名といら，やは り医療先進国の一つに数光られるわが国でも，昭和 51 年 の調查 ${ }^{18)}$ 亿よると, 地域住民㳔する保健・医療情報の 提供活動にはいろいろの問題がめり, 一般住民は, (1)応 急手当の方法, (2)病気発見に役立つ知識, (3)病人の世話 の仕方の知識，などを特に必要と感じていると報告され ている。そしてそれらの知識の獲得手段としては, マス コミ媒体と医師・看護婦からが同率で 1 位を占め, それ 飞家族, 友人, 薬局の人, 家庭医学書などが順次続いて いる。又, 6 社の出版社から出版されている家庭医学書 は初版以来 592.3 万部を発行し，その実際の売上げ部数 を70\%とみても全国の総世帯に対する普及率は約 $12.9 \%$ となっている。

最近, 世界保健機構WHOが盛えに唱えているプライ マリー・ヘルス・ケアといら動きる，医療先進国ではへ ルス・マンパワーの增加などにむすびつけ，アメリカで は Area Health Education Center (AHEC) の設置な ぞの形で表現されたりしているが，後進諸国では，医師
の不足という現実の中で地域住民が自衛できるように少 しでも保健・医療の知識を与えるように努力することが 大きな目的であるという。

このような現実の必要とは少し異るが，消費者運動と して，「知る権利」といら形で，地域住民が保健医療情 報を要求する運動の台頭がもう 1 つの原因で㐫る。「コ ーシューマー・ヘルス・インフォメーション」と呼ばれ て物り，アメリカに执いて，殊飞活発な動きを示してい る。素人である一般地域住民が自分達自身の健康という ことについて，もっと積極的な責任を取るべきであると いう考光に基き，ニューヨーク市には the Conter for Medical Consumers and Health Care Information $\varepsilon$ 呼ばれる，消費者としての一般住民のための保健医療情 報のセンターが1976年に設立された。ここでは“Health Facts”という出版物を出したり，図書館サービスを提 供したり，TEL-MED という医学・医療情影のオーディ オ・テープを使用しての電話によるダイアル・アクセス ・サービスを提供したりしている20)。

わが国の場合には，ぞちらの動きも未名惊っきりは現 われてきていないが，ぞらで市れ，一般地域住民に対す る保健・医療情報提供サービスが医学図書館の仕事の大 切な一部門になる時代が訪れるのは, 諸外国の例からみ ても明らかなことである。ただこの面でも，患者に対す る図書館サービスの提供のように, 大学医学㘠書館より 病院図書室の注らが先に動き出すことになるかも知れな い。アメリカに括㱂院図書室のこのような活動につ いては, ニューヨーク州ブロンクスビルのLawrence 病 院図書室のライブラリアンである Topper がよい解説を 特こなっている3せ

このような動きの中でる特に知られているのは，口ス アンジェルスの Harbor 総合病院の図書室と Carson 地 区公共図書館の両者が協力して, 地域住民に対する保険 - 医療情報の提供を目的として1976年から始めたCHIPS (Consumer Health Information Program and Service) 計画である ${ }^{12)}$ 。の両図書館が置かれている地区の住民 約 200 万人のうちの $26 \%$ ガスペイン系であるので，これ らの住民の情報要求にも応じるために, 英語のものと一 緒にスペイン語のTEL-MED のテープも準備している。 又, 対象地域の保健医療関係の諸機関との間汇情報交換 を行うシステムを確立し，関係職員の地域保健医療情報 サービスに関する教育を行ない，対象地域の住民がこれ らの保健・医療情報化，接しやすくすることに努めてい る。 
勿論，以上のような動向というものは総ての医学図書 館に見られる訳ではなく，まだまだどちらかと言えば例 外的な, そしてそのために注目されている活動であると 言えよう。しかし，一般の医学部の図書館などで，患者 や一般地域住民などに対するサービスを積極的には行っ ていない場合でも, それらの人達の利用はこばまないと いった傾向は強くなってきている。Jeuell の調査 ${ }^{16) 17}$ に

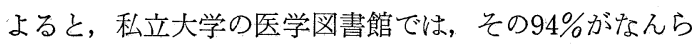
かの形で地域住民に対してその門戸を開放しているとい う。しかし利用対象については, 法律家, 他大学の学生 や教員, 医学・医療関係者等々に限るといら制限を設け ているところが多い。一方, 州立などの公共の大学の場 合には，91\%がそのサービスを一般住民に開放している が，利用対象の制限は私立の場合より少い。一般住民に 対するクイック・レファレンス・サービスの提供は, 両者 ともに活発に行っているが(州立 $82 \%$ ，私立 $63 \%)$ ), 手間 のかかる情報提供サービスになると，少くなっている (州立 $32 \%$ ，私立 $23 \%$ )。文献探索は，索引誌などを使用 した人手によるサービスの場合は，州立 $68 \%$ ，私立 $57 \%$ と, 行っている機関がさほど多くなく，しかも，サービ ス対象に制限を設けているところも多かったが，コンピ ュータによる機械検索サービスに関しては, 州立 $88 \%$, 私立 $83 \%$ と非常に多くの機関が，利用対象の制限なしに 执こなっていることが判明した。これは多分, 機械検索 の場合には費用が徴収し易いという理由によるためであ らうといらことである。

いずれにしても, このように多くの大学医学部図書館 が，その地域住民に対してもサービスを行なら必要を感 じ，それを実行に移しているという事実は，最近の新し い傾向と言光よう。只その場合でも, 大学医学部図書館 としては, 公共図書館と協力し, それを通して一般住民 そサービスを，提供してゆくことを望しでいるょうであ る。

このような動きは，わが国の現状からみると，まだま だ縁遠いことのように思われるが，乙かし徐々に世界的 な風潮となり始めていることは明らかで，いずれわれわ れも直面することになる問題と思われる。

さて, 以上の上うに「医学図書館」は「保健科学図書 館」(health seience library) となり, そのサービス対 象が急激に拡がり出しているが，その一方，従来からの 利用者でめった医師に対するサービスについての見直し も行われ始めている。

アメリカでは，1970年の，「高等教育と国民の保健」
に関する，カネギー委員会の報告とその勧告に基き，各 地域池地域保健教育センター Area Health Education Center (AHEC) が設けられ, 医学・医療従事者の配置 の地域による格差の解消へと, 国としての努力が一段と たかまってきている。医学図書館関係者も，この機会を 積極的汇掝えて, AHEC に対する図書館サービスの強 化を計ることにより，地区図書館計画 (RMLP) で築い た医療過柾地域に対する図書館サービス網を，更に整備 されたものにしようと努力している10377。またその動き と共汪，それらの地域に住む医師がぞの上うな情報を必 要としているのかといった根本的な問題に対する調査も 行われるようになってきた。従来も, 一つの図書館の利 用者の調查であるとか，一つのサービスの利用の評価み たいなことは少しは行われてきたが，西る地域の医師の 情報要求調查となるとは, ほとんど皆無と言って良かっ た。Strasser がニューヨーク州の北東部地域の 医師を 対象飞行った調查 ${ }^{32}$ 性, 市場調查の手法を取入れて行っ たもので, 種々の面白い結果を出している。その幾つか をあげると次のと和りである。この地域の医師は 1 人平 均 4.1 種の医学雑誌を購読して特り，40\%以上の医師が 5 種以上購読している。又, 内科医, 小児科医, 外科医 産婦人科医, 放射線医学専門医などの, グループのもの は, 皆, 自分の専門分野の新しい進歩についての情報を 第 1 亿欲しているのに対して, 家庭医と麻醉専門医のグ ループのみは薬についての情報を第 1 としている。そし て自分の専門についての情報は麻酔專門医では, 第 2 位 の心藏病についての情報についで, 保健・医療について の政府関係の法律・規則に関する情報とならんで，第 3 位にして法り, 家庭医に到っては, 癌の情報, 心藏病の 情報, 病気の心理学的側面についての情報について, 日 常の患者診療に関する情報と並んでやっと第 5 位にあげ ている。

情報源としては, 定期刊行物の論文が圧倒的に高いポ イントで第 1 位にあげられて特り，続いて仲間との，個 人的な接触が第 2 位となっている。しかし, 産婦人科医 のグループのみは, 仲間,との個人的接触を第 1 位にあげ 第 2 位に図書をあげ，第 3 位に雑誌をあげている。全グル 一プ全部を平均した場合には，第 1 位が定期刊行物の論 文, 第 2 位が仲間との個人的接触, 第 3 位が図書, 第 4 位がセミナー, ワークショップ, コンファレンス類, 第 5 位が自分の情報ファイル，第 6 位が抄録誌，第 7 位が 四書館のレファレンス・サービスとにり，9位にはビデ オ・スライド，オーディオ・テープなどのニュー・メディ 
ア類, 10 位に新聞類, 13 位に索引誌, 15 位に current awareness サービス，18位にコンピュータによる情報サ 一ビスなどがあげられている。一つの傾向としては若手 の医師の活うが高齢の医師よりも，定期刊行物の論文を よく読み, 且つ, ビデオ, テープ, その他のニュー・メ ディアを使用し，コンピュータの情報サービスを活用し ているといらことが指適されている。

社会環境の変化と共に, 保健・医学関係図書館に対す る利用者の要求む, 当然変化してきている筈である。昨 日の要求が今日の要求と同じであるという保証はない。 わが国に和いても，医学図書館の今後の発展を望むため には，保健・医学・医療をめぐる社会の変化に注意を払 い, その動いて行く方向学十分に見極めて, 医学図書館 の長期にわたる活動方針を定めていくことが必要である と共に，現在とのサービスを提供している利用対象の実 際の情報要求についても, 種々の角度から調査して, 適 切な情報サービスの提供と心がけるべきであらう。

\section{II. 技術の変化と医学図置館}

社会的変化とは異った意味で医学図書館に大きな変化 を与觉ているのが，コンピュータの利用を主体とした技 術の進歩である。医学図書館は従来から新しい技術を取 り入れるのには積極的であり，前述のようにわが国に和 いても, ゼロックスの導入, テレックスの利用, 文献コ ピーのファクシミリ電送実験等, すべて他の館種に先駆 けて行ってきている。アメリカに㧤いても, 現在の国立 医学図書館 (N LM) の前身である陸軍医学図書館Army Medical Library が, 国立保健研究所 (N I H) の図書 館や, ジョンズ・ホプキンス大学の医学図書館と協同 で, 既に1940年代の後半から1950年代の始めにかけて, I BMの統計機を利用しての文献探索実験を行ったり, 又ファクシミリ電送実験までも行っていた。そして, 1964年からは，MEDLARS によりコンピュータを使用 した Index Medicus の作成, 执よびその機械検索サー ビスを開始し，世界的な 2 次資料のコンピュータ化の先 鞭をつけている。

この MEDLARS の利用は, UCLA の G.Werner の 調査 ${ }^{36)}$ で報告されているように, 1971年にオンライン 検索が MEDLINE として実行に移されるや，その使用 が急激に増加し，1977年にはこれを利用する機関がアメ リカ国内及び国外で 800 に達し， 1 年間に 90 万件ものオ ンライン及びオンラインによる検索が拈こなっている。 しかも，この利用の伸びは，立沢の報告33の中にある
1975年までの伸び率を示す図からも明白なように非常に 高い伸び率を示して和り，今後益々その利用が伸びてい くことは明らかである。おが国の場合にも, 世界の他の 先進諸国に比べると, MEDLARS/MEDLINE の導入こ そやや立ら遅れ気味であったが，日本科学技術情報セン ター (JICST) その他の関係者の努力により, その利用 も着実に伸び始めている。即ら, MEDLINEのオンライ ン検索開始の年の1976年には，971 件であった年間利用 件数が，1977年には約 4 倍の3,742件となり，1978年に は，11ヶ月で10,746件にまで達している程である。そし て, 1979年 4 月には, 医薬関係企業35台, 医学系大学 35 台, 病院 6 台, 合計 76 台と, 医学関係機関での MED. LINE を利用する端末機設置台数が，前年のそれの $81 \%$ も增加することになっている。

保健・医学・医療分野に和いて必要とする文献は, 医 学分野のものばかりでなく, 最近に执いては, 従来から. その隣接領域と考えられていた生物学, 化学, 物理学, 心理学, 統計学は勿論, 更には, 社会学, 経済学, 法律 などの領域のものまでも含まれるようになってきた。従 って, MEDLARS/MEDLINE 特よび, CATLINE, TOXLINE, CANCERLIT その他の, NLM で作成さ れているデータベースのみの利用では, 医学図書館利用 者のすべての文献探索要求に応じることは, 不可能であ る。総ての文献探索要求をコンピュータによる機械検索 で処理しょうと思觉ば, Excerpta Medica, CA Condensate, CASIA, BA Preview, SCI, SSCI, NTIS, ERIC その他数多くのデーター・ベースの併用を必要とする。事 実, アメリカに和ける保健・医学系図書館の多くは, MEDLINE の他に Lockheed, SDC, BRS などのサービ ス機関のサービスを併用して，これらのデータ・ベース の検索も物こなっている。又, わが国に特いても, 東京大 学, 筑波大学, 広島大学などでは幾種ものデータベース を購入して, 外部の利用者からの利用にも応じる体制を 着々と整え始めている。その上, 丸善, 紀伊国屋などに よる Lockheed などそ利用するサービスの提供す行われ ている。

殊に特記すべきこととしては，文部省が計画している 学術情報サービスのネットワークがある。これは文献そ のものの組織的な蓄積・提供を計ると共に, 主要データ ベースを集中的に収集して，その検索サービスを図書館 などの空口を通じて，オンラインで全国の研究者に提供 することを考劣ている。その実現の暁には，保健・医学 分野の研究者は, 大学関係の医学図書館の空口を通じて 
必要とする文献の大部分を，迅速に検索できるようにな る。但し, この場合でも日本語の医学文献は, これら既 存のデータ・ベースに注とんど收録されていないので, その為の特別なデータ・ベースを作成しない限り, 従来 ぞ抢りの手作業による文献探索に頼る他はない。幸いな ことに, 最近になってこの方向への動きが起り始めてい るが，その収録すべき文献量から考光ても，過去に遡っ てのデータ・ベース化は不可能に近く, 従って, その計 画が遅れれば遅れるほぞ, 日本の医学文献の検索の不便 さは增すことになる。

医学文献のデータ・ベースに関係しては, 日本語によ る医学雑誌論文の持つ意味についての考慮をする必要が あろう。澤并 ${ }^{27223)}$ の調査によると, 1976 年 1 年間泟,

Science Citation Index に収録されている世界の主要な 医学雑誌 975 誌中の 426 誌に, 日本の研究者の論文 2,247 編が投稿されている。又, 耳鼻咽喉科の研究者の及を取 ると，1967年から1976年の10年間に，それらの雑誌に投 稿された日本の研究者の論文数は 257 編で，その著者数 は 542 人で㐫った。そして，これら外国雑誌投稿者の数 は明らか增加して和り，年間投稿論文数も大体增加の 傾向に㟧る。又, レビュ一専門誌 Year book of Otola ryngology に収録される数は，横ばい状態であるが，そ れらの論文は従来は外国人との共同研究によるものが過 半数であったものが，現在では日本人のみによる論文が 過半数を占めるようになっている。

上田和よび中山の調查では, 自然科学全分野比対する 同様の調査 ${ }^{55}$ 報告を行っている。この報告によると生命 科学の分野での外国雑誌に対する日本の研究者の投稿は 多いが，臨床医学分野の投稿は，他の分野と比較すると 余り多くない。しかし，年々着実に增加しているのは明 らかで梁る。これら国際的な一流誌への投稿論文数の多 少は, 語学面での条件を考慮する必要はあるが, 大体に おいて，その国の研究の質と量の面を反影していると言 われている。しかて，一方に括いては，日本の医学関係 雑誌論文を網羅的に収録している「医学中央雑誌」の年 間収録論文数は, 年間 $12 \sim 3$ 万の数にも達している。こ れら日本の医学関係雑誌論文の研究, 診療, 教育などの 面の情報伝達活動で持つ意味というもの学十分に考慮し た上で，目的に適ったデータ・ベースを作成するよう努 めるべきであろら。

このようなデータ・ベースの利用の積極化は, 少くと も次の 5 つの点で今後のわが国の医学関係図書館に大き な影響を与えることにならう。その第 1 は, 従来の日本
医学図書館協会のネットワークの外飞ある，これらデー タ・ベースを持つ機関との新しい関係の成立である。既 飞 MEDLARS のデータ・ベースを使用するために, JICST と協会加盟館とのより密接な関係が生じ始めて いる。更に, Excerpta Medica その他のデータ・ベース の使用を考光た場合には, 筑波大学や東京大学などの大 型コンピュータ・センターとの関係が必然的に生れてく ること店る。そして医学・医療情報の検索サービスの 利用者も，これらのデータ・ベースを持つセンターを中

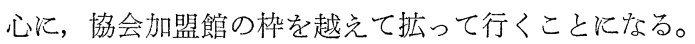
又，こ机らデータ・ベースの作成者との関倸学考光た場 合は，その繫りが広く国際的なものになでなって行くこ とは明らかである。

第 2 亿，既に第 1 で述べたような、コンピュータ・セ ンターと図書館との関係の強化で专る。今後, 雨者は同 じ情報を扱う機関として, 同じ大学内でも, 更には大学 の棵をこ壳て，その連帯を強めて行くことになるである う。現在, 大学のコンピュータ・センターの予算は, 大学 図書館の予算規模に近づいてきて蛒り，アメリカなどの 大学では, 両者の学術情報活動に和ける有効性, 経済性 を比較する動きすら出始めている一方，両者を同じ系列 の組織として扱ら試みもされているという。

第 3 には，文献検索サービスが盛んになるにつれて， 図書館は，検索の結果見つかった文献そのものの提供が 求められるため, 従来以上に多くの資料の収集蓄積を必 要とするようになる。しかし，個々の図書館の藏書を強 化するのは自ずから財政的にも限界があるので，国全体 として総合的な見地から見ての図書資料の蓄積を強化す ると共に，総合目録を整備して，相互貸借活動を通じて 必要な人へ必要な文献を提供し得るようにしようという のが全世界的な傾向である。そして，国として藏書を強 化するのには大体二つの型が屴る。一つは，イギリスの 場合のイギリス図書館貸出部門 BLLD のように, 世界 中の雑誌などを集中的に収集する䫏出センターを設ける 方法であり，もら一つは，西ドイッなどの場合のように 特定の図書館を特定分野の雑誌などの資料収集の拠点図 書館として，国が特別の予算措置をするといら方法であ る。わが国では文部省により，西との方法が進められて 特り, 現に医学の分野では, 大阪大学附属図書館中之島 分館が拠点図書館に定められて和り, 更に九州大学と, 東北大学の医学部分館が，サブの拠点図書館となってい る。

第 4 には，オンラインによる文献検索サービスが主と 
して図書館の参考係りを仲介に行われるため, 図書館員 飞対する医学知識の教育の強化が必要になる。前述の, Werner ${ }^{36)}$ の調查でも，アメリカおよびカナダに执惊る MEDLINE 検索の $80 \%$ が図書館員の艾によって行われ ており，20\%が，探索申达者が側淿て，やはり図書館 員によって行われていて, 研究者が自分で検索する件数 は1\%に満なないことが明らかにされている。わが国の 場合は, 四書館員が医学・医療の主題内容にまで立ち入 る習慣が余りないので, 検索の責任が図書館員化全面的 飞かかってくるかどらかは判らないが，少くとも今まで より遙か溞く, ある程度の医学・医療の知識学学ぶこ とが図書館員に要求されてくるよらになるのは確実であ る。

第 5 は, 文献検索が迅速に出来るようになることと, 社会的空要求とが相俟って, 文献情報サービスが診療の 場に対してる, 上り積極的に提供されるようになること は，アメリカに和けるCMLサービスや，患者や地域住 民対する保健情報の提供サービスの台頭を見ても疑う 余地沈ない。

コンピュータの図書館に䑙ける利用のもら一つの面と しての library automation も, 初めに予想された程に は急激に発展しなかったが，乙かし着実注歩し続けて いる。MEDLARS の検索の評価で有名な，イリノイ大 学の Lancaster 教授が晿光る紙を使用しない "Paperless”情報システム19) が現実のるのになる時代が来るに せよ, 又 Brandon ${ }^{32}$ が主張するように, 図書といらるの は依然として必要なものとして残るにせよ，コンピュー タが図書館情報サービスに执いて，現在よりるっと盛ん 飞使用されることは確かであろう。事実現在でも, 文部 省の科学研究費により, 社会科学, 人文分野の雑誌の総 合目録のコンピュータによる編集が研究され, 且つ実行 に移されている。又, 筑波大学のコンピュータ・センタ 一（学術情報センターといら名称が与兄らている）に 要る LC-MARC と UK-MARC のデータ・ベースを東 京, 千葉, 名古屋, 京都などの大学図書館がオンライン で使用して，その目録作成，検索大学からの目録情報の インプットなどについての実験も行っている。更にその 他には，貸出のレコードのオンラインによるコントロー ルを含めた大学図書館のトータル・システムの開発も進 められている。

このコンピュータの利用よりも，更にゆるやかな動き を見せながら，やはり徐々に医学・医療情報活動の中に その地位を固めてきつつあるのが，いわゆるニュー・メ
ディアと呼ばれるタイプの資料で市らう。その主力はフ ィルム，ビデオ，オーディオ・テープなどであるが，ア メリカでは主として医療従事者の生涯教育などの面で比 較的よく使用されているし，今後益々乞の使用が増加す るのは明らかであるが，現在では未だ経済性など疑問が 持たれている。

\section{III. 結論}

以上述べて来たように, 医学図書館は今日大きな変化 の時代迎克ようとしている。その一つの原因は社会的 なるのであり，もら一つはコンピュータを中心とした技 術的なるのである。

前者は, 保健・医学・医療の情報といらもの定, 従来 の研究・教育での利用の及を主体としたものから，診療 の場へ, 医師の久文対象之したものから医療従事者全体 へ，更に患者を含めた一般地域住民へと押し拡げて打り この利用対象の拡りは，専門知識を非専門家にも判るょ うな, やさしい形で伝達する popularization といら機 能を, 医学図書館の新しい仕事として追加する必要を生 じせしめている。

後者は, 伝統的に図書と雑誌といった印刷物形式の情 報媒体のみを取扱っていた図書館員に，マシン・リーダ ブル・データ・ベースであるとか, ニュー・メディアで あるとか，種々の異った情報媒体とも取組むことを求め て搂り, 更には, テレ・ュミュニーケーションの綱目を 使って，地域的，全国的，又は国際的な情報サ一ビスの 形成に努めることを求めている。

これらの変化は，過去 20 年の間江急激汇顕在化してき たため，医学図畫館は，それぞれの異った要求泣対する 対処にとまどっているといったところが穾情であろう。 しか子, わが国の場合には, 欧米諸国といろいろな面で 条件が異るため, 今迄のところ，この变化の波が比較的 ゆるやか炠し寄せて来ているため, 現場の図書館での この変化に対する認識を, か党って難しいものにしてい るよらに思われる。

現在，われわれの取る方法は二つある。一つは思い切 って, 図書・資料の書庫としての機能澈して, 新たに 必要とされるようになった機能は, コンピュータ・セン ターなり，その他必要迫られて新た怕生れてくるであ ろら組織なりにまかせてしまうことである。もら一つは 何とか現在の図書館の組織や, 機能をつくりか光て, 出 来る限り新しい要求に, 応じられるよらにすることであ る。そして若し, 後者を選ぶとしたならば, 主題知識に 
ついて学ぶことも含めて, 医学図書館員の思い切った体 質改善を計る必要があうう。

\section{文献}

1) Algermissen, V. : Biomedical Librarian in a Patient Care Setting at the University of Missouri-Kansas City School of Medicine. Bull. Med. Libr. Assoc., 62 (4) : 354-358, 1974.

2 ) And now "Clinical Librarians" on Round. JAMA., $230: 521,1974$.

$3)$ Brandon, A. N. : The Controversy over Change. Bull. Med. Libr. Assoc., 66 (1) : 1-5, 1978.

4) Claman, G. G. : Clinical Medical Librarians : What They Do and Why. Bull. Med. Libr. Assoc., 66 (4) : 454-456, 1978.

5 ) Clinical Librarians Accompany Physicians on Rounds. NLM News, $29: 3,1974$.

6) Colaianni, L. A. : Clinical Medical Librarians in a Private Teaching Hospital Setting. Bull. Med. Libr. Assoc., 63 (4) : 410-411, 1975.

7) Cornelisse, L. : A Clinical Reference Program in the Department of Medicine, Tufts-New England Medical Center Hospital. Bull. Med. Libr. Assoc., 66 (4) : 456-458, 1978.

8) Dragonette, D. B. : Health Science Library's Contributions to Patient Care. Bull. Med. Libr. Assoc., 61 (1) : 29-32, 1973.

9) Dunkel, L. M. : Library to Patient: New Role for the Patients' Librarian. Bull. Med. Libr. Assoc., 64 (4) : 418-419, 1976.

10) Evans, A. et al. : Evaluation of a Library Pro. gram in a Carnegie Model Area Health Educa. tion Center. Bull. Med. Libr. Assoc., 66 (2): 190-199, 1978.

11) Farmer, J. and Guilaumin, B. : Information Needs of Clinicians : Observatioes from a CML Program. Bull. Med. Libr. Assoc., 67 (1) : 53-54, 1979.

12) Goodchild, E. Y. et al. : The CHIPS Project : a Health Information Network to Serve the Consumer. Bull. Med. Liber. Assoc., 66 (4) : 432436, 1978.

13) Greenberg, B. et al. : Evaluation of a Clinical Medical Librarian Program at the Yale Medical
Library. Bull. Med. Libr. Assoc., 66 (3) : 319326, 1978.

14) Greenberg, B. et al. : MEDLINE Demand Profiles : an Analysis of Requests for Clinical and Reserch Information. Bull. Med. Libr. Assoc., 65 (1) : 22-30, 1977.

15) Harris, C. L. : Hospital-Based Patient Education Programs and the Role of the Hospital Librarian. Buil. Med. Libr. Assoc., 66 (2) : 210-217, 1978.

16) Jeuell, C. A. : Brief Survey of Public Information Services at Privately-Supported Medical School Libraries: Comparison with PubiclySupported Medical School Libraies. Bull. Med. Libr. Assoc., 65 (2) : 292-295, 1977.

17) Jeuell, C. A. : Public Information Service at State-Supported Medical School Libraries: A Brief. Survey. Bull. Med. Libr. Assoc., 64 (4) : 415-417, 1976.

18）国民の医療・保健の実態と動向の総合研究—生活 構造の变化と社会機能の関連の解明, 東京, 国際医 学情報センター, 1976. （NRS-75-2 総合研究開発 機構助成研究)

19) Lancaster, F. W. : Toward Paperless Information Systems. New York, Academic Press, 1978.

20) Levin, A. A. : Medical Consumerism and Health Information. Bull. Am. Soc. Inf. Sci., 4 (4) : 19, 1978

21) Lunin, L. F. : Information for Health is an is. sue: Opportunities for Information Scientists in Health Care Information. Bull. Amer. Soc. Inf. Sci., 4 (4) : 11-12, 1978.

22) Marshall, J. G. and Hamilton, J. D. : The Clinical Librarian and the Patient: Report of a Project at McMaster Uuiversity Medical Centre Bull. Med. Libr. Assoc., 66 (4) : 420-425, 1978.

23) New Roles for Health Science Librarians-4 MLA News, $60: 5,1974$.

24) Richards, D. J. : Providing Health Care Information to Patients in a Small Hospital. Bull. Med. Libr. Assor., 66 (3) : 342-345, 1978.

25) Roach, A. A. et al. : The Effect on an Informa-. 
tion Specialist on Patient Care and Medical Education. J. Med. Educ., 50 (2) : 176-180, 1975.

26) Roth, B. G. : Health Information for Patients : the Hospital Library's Role. Bull. Med. Libr. Assoc., 66 (1) : 14-17, 1978.

27）澤井 清：わが国の生物・医学研究者の外国雑誌へ の揭載傾向についてーSCI（1976年）を利用した調 查一. Libr. Inf. Sci., $15: 49-66,1977$.

28）澤井 清: わが国の耳鼻咽喉科研究者の発表した欧 文研究論文：SCI（1967ー1976）を利用した調查。 Libr. Inf. Sci. $16: 79-92,1978$.

29) Schnall, J. G. and Wilson, J. W. : Evaluation of a Clinical Medical Librarianship Propram at a University Health Science Library. Bull. Med. Libr. Assoc., 64 (3) : 278-281, 1978.

30) Sowell, S. L. LATCH at the Washington Hospital Center, 1967-1975. Bull. Med. Libr. Assoc., 66 (2) : 218-222, 1978.

31) Staudt, C. et al. : A Clinical Librarians' Program -an Attempt at Evaluation. Bull. Med. Libr. Assoc., 64 (2) : 236-238, 1976.

32) Strasser, T. C. : The Information Needs of Practicing Physicians in Northeastern New York State. Bull. Med. Libr. Assoc., 66 (2) : 200209, 1978

33）立沢 寧 : 医学・医療の情報管理の将来, 医学図書 館, 23 (4) : 175-189, 1976.

34) Topper, J. M. : Hospitals as Centers for Consumer Health Information. Bull. Amer. Soc. Infor. Sci., 4 (4) : 13-14, 1978.

35）上田修一，中山和彦：国際的学術雑誌と研究者の投 稿傾向, Libr. Inf. Sci., $16: 67-78,1978$.

36) Werner, G. : Use of On-Line Bibliographic Retrieval Service in Health Sciences Libraries in the United States and Canada. Bull. Med. Libr. Assoc., 67 (1) : 1-14, 1979.

37) West, R. T. : Area Health Education Centers and Health Science Library Services. Bull. Med. Libr. Assoc., 65 (3) : 368-376, 1977. 